\title{
THE DEMONSTRATION OF TYPE SPECIFIC STREPTOCOCCAL ANTIBODY BY A HEMAGGLUTINATION TECHNIQUE EMPLOYING TANNIC ACID ${ }^{1}$
}

\author{
By FLOYD W. DENNY, JR., AND LEWIS THOMAS \\ (From the Heart Hospital Research Laboratories, Department of Pediatrics, The Medical School, \\ University of Minnesota, Minneapolis, Minn.)
}

(Submitted for publication May 18, 1953; accepted July 1, 1953)

Immunity to the group A streptococcus has been shown to be associated with the formation of antibody against the type-specific component of the streptococcus, the M protein of Lancefield $(1,2)$. The techniques that have been employed in studies of this antibody include agglutination (3), precipitation (4), mouse protection (5), and bacteriostasis $(6,7)$. For practical purposes, in the study of human infections, all of these methods except the bacteriostatic test have proved to be unsatisfactory. The latter test, as described by Rothbard (7), yields reliable results but the numerous technical difficulties inherent in the procedure have made it desirable to find another method for the demonstration of type specific antibodies.

The presence of various antibodies has been demonstrated by the adsorption of antigenic components of bacteria to the surface of erythrocytes, rendering the cells agglutinable by specific antisera. The widest application of this technique has been in the demonstration of antibodies to a component of the tubercle bacillus $(8,9)$; the technique has also been applied in serological studies of $\mathrm{H}$. influenzal meningitis (10), histoplasmosis (11), glanders (12), scrub typhus (13), mumps (14), tularemia (15), streptococcal infections and rheumatic fever (16), and infections with $E$. coli (17).

In this laboratory, repeated attempts were made to adsorb $M$ protein to erythrocytes and then demonstrate their agglutination by specific antibody. No adsorption could be demonstrated, even when erythrocytes from sheep, rabbit, and man were ex-

1 This work was done under the sponsorship of the Commission on Acute Respiratory Diseases, Armed Forces Epidemiological Board, and was supported in part by the Office of the Surgeon General, Department of the Army.

The studies were also aided by grants from the United States Public Health Service (HG923), the Minnesota Heart Association, and the Medical Research Fund of the Graduate School, University of Minnesota. posed to high concentrations of the antigen for prolonged periods. Other methods were then sought which would modify the cell surface and facilitate the adsorption of $M$ protein. Peck and Thomas (18), in a study of the capacity of tannic acid to render erythrocytes susceptible to hemolysis by human complement, demonstrated that tannic acid has an apparent affinity for both red cells and complement, and when adsorbed on the cell surface is capable of bringing complement, or a component of complement, into close relation with the cell surface. The concentration of saline used as a diluent was of major importance, 0.7 per cent saline proved to be optimal. Human red cells treated with tannic acid were not susceptible to lysis by sera from the rabbit, guinea pig, mouse, or sheep.

Boyden (19), by treating sheep erythrocytes with tannic acid prior to adsorbing P.P.D. antigen to their surfaces, was able to detect antibodies in sera from tuberculous patients in dilutions up to 100 -fold greater than those shown by the direct sensitization technique of Middlebrook and Dubos (8). The results of the two methods, however, did not always correlate and the author suggests that more than one antibody may have been involved. By the same technique ovalbumin, horse serum globulin and albumin, chicken globulin, and a streptococcus protein preparation were adsorbed to sheep red cells, and the cells were agglutinated by the corresponding antibodies.

The present paper is concerned with the demonstration of type-specific antibodies against the $M$ protein of group A streptococci, by a hemagglutination reaction involving human erythrocytes treated with tannic acid prior to the adsorption of $M$ antigen.

\section{MATERIALS AND METHODS}

Human erythrocytes. Human group O blood was collected aseptically in equal volumes of Alsever's solution 
(20) and stored at $4^{\circ} \mathrm{C}$. The erythrocytes so stored could be used for several weeks. At the beginning of each day an aliquot of cells was washed three times in normal saline and was then ready for use. Satisfactory results were also obtained with group $O$ blood-bank cells which had been collected within the preceding several days. When blood bank cells were used they were collected by centrifugation and added to equal volumes of Alsever's solution.

Saline solution. Saline solution was used in a concentration of 0.75 per cent in all parts of the procedure except in the initial washing of the erythrocytes. The advantages of this concentration of saline over normal saline were that nonspecific agglutination occurred less frequently, and the agglutination pattern of the erythrocytes was easier to read.

Tannic acid. Fresh tannic acid solutions were prepared daily using 0.75 per cent saline as the diluent. Mallinckrodt tannic acid (analytical reagent, lot number 1764) was used throughout these experiments.

$M$ protein. M protein of group A streptococci was prepared by the acid hydrolysis method of Swift, Wilson, and Lancefield (21), and the group specific C polysaccharide was removed by several extractions with 95 per cent ethyl alcohol (22). The final product was suspended in $8 \mathrm{cc}$. of normal saline per liter of original culture and was designated as "undiluted" $M$ protein. Various dilutions of this material were prepared in 0.75 per cent saline. These preparations consist of only partially purified $\mathbf{M}$ protein but for convenience will be referred to in this publication as "M protein." It should also be emphasized that $M$ protein is a mixture of heterogeneous proteins, and there is no available method for determining whether various antigenic properties of this material are due to the activity of a single substance or a multitude of substances.

Sera. Type-specific antistreptococcus rabbit sera were obtained through the courtesy of the Public Health Service Communicable Disease Center Streptococcus Laboratory, Chamblee, Georgia, and sera from patients with streptococcal infections were provided by the Streptococcal Disease Laboratory, Warren Air Force Base, Wyoming. All sera were heated at $56^{\circ} \mathrm{C}$. for 30 minutes before use.

Complement. The complement used was lyophilized guinea pig complement (Lyo Complement, Sharp and Dohme). Dilutions of complement were made with 0.75 per cent saline solution.

Sensitization of erythrocytes with tannic acid. One volume of tannic acid solution was added to two volumes of 1 per cent erythrocyte suspension and allowed to stand at room temperature for 30 minutes. The treated cells were then washed three times with 0.75 per cent saline solution.

Adsorption of $M$ protein to erythrocytes treated with tannic acid. One part of tannic acid treated erythrocytes was added to fifty parts of the desired dilution of $\mathbf{M}$ protein and the mixture placed in a water bath at $37^{\circ} \mathrm{C}$. for one hour, shaking sufficiently to resuspend the cells after the first 30 minutes. The cells were washed three times with a 0.75 per cent saline solution and then diluted to make a 2 per cent suspension. The final dilution in most experiments was made in 0.75 per cent saline; in some it was made in a $1: 100$ dilution of normal rabbit serum in 0.75 per cent saline. These erythrocyte suspensions were used in the final test and were satisfactory for use only on the day of preparation.

Hemagglutination test. Chromic acid-cleansed $100 \times 13$ $\mathrm{mm}$. test tubes were used in all tests. Serial dilutions of sera were made in 0.75 per cent saline or, in some of the experiments to be described, in a 1:100 dilution of normal rabbit serum in 0.75 per cent saline. To $0.2 \mathrm{cc}$. amounts of each serum dilution was added $0.2 \mathrm{cc}$. of the erythrocyte suspension. The tubes were incubated in the $37^{\circ} \mathrm{C}$. water bath for two hours, shaking at 30 minute intervals, and then placed at $4^{\circ} \mathrm{C}$. until the following morning. After 30 minutes at room temperature, readings were made by the pattern of the red cells on the bottom of the tube. When agglutination occurred, the cells settled out in a wide area, with varying degrees of clumping. In negative tests, the cells formed a small button in the tip of the tube. Readings could not be made by agitation of the tubes and observation of suspended clumps of agglutinated erythrocytes, since even those showing maximal agglutination were readily dispersed by shaking. The titer of agglutination was considered to be the highest dilution of serum showing definite clumping, and was designated by the dilution of serum before mixture with the erythrocytes.

Controls were run with all tests and included erythrocytes treated with tannic acid and $M$ protein with no serum present, and erythrocytes treated with tannic acid alone.

Hemolytic test. The hemagglutination test could, under certain conditions described below, be converted into one involving hemolysis instead of agglutination. This was accomplished by adding to each tube in the agglutination test, after overnight refrigeration, $0.2 \mathrm{cc}$. of a $1: 5$ dilution of guinea pig complement. Readings for hemolysis were made after 1 hour in the $37^{\circ} \mathrm{C}$. water bath.

\section{EXPERIMENTAL RESULTS}

The optimal concentration of tannic acid. Since hemagglutination is known to occur in the presence of tannic acid alone, it was first necessary to determine the concentrations of this material which could be used without causing agglutination. To do this, various concentrations of tannic acid were added to a 1 per cent solution of washed red cells, in the proportion of one volume of tannic acid to two of cell suspension. The mixture was allowed to stand at room temperature for 30 minutes, and the cells washed three times. The erythrocytes were then resuspended in 0.75 per cent saline to make a 1 per cent suspension, placed in the refrigerator overnight, and read for agglutination. Definite agglutination occurred in cell suspensions which had been exposed to tannic acid in concen- 
trations higher than 0.004 per cent; the concentration of 0.004 per cent caused questionable agglutination; concentrations of less than 0.004 per cent caused no agglutination. On the basis of this observation a concentration of 0.001 per cent was arbitrarily selected for use in all the subsequent experiments to be described.

The optimal concentration of $M$ protein. Cells which had been treated with tannic acid were found to be rapidly agglutinated by the addition of $M$ protein, when sufficient concentrations of the protein were used. Untreated erythrocytes were not agglutinated by the same or higher concentrations. It was therefore necessary to titrate $M$ protein in the presence of treated cells in order to find a concentration in which interference by this type of agglutination did not occur.

Dilutions of $M$ protein were added to erythrocytes treated with 0.001 per cent tannic acid; the mixtures were incubated at $37^{\circ} \mathrm{C}$. for one hour, and the red cells washed three times and resuspended in 0.75 per cent saline to make a 1 per cent suspension. A reading for agglutination was made after overnight refrigeration. Agglutination of tannic acid treated cells occurred with all $M$ protein preparations in dilutions of $1: 25$ or less and with some preparations in dilutions as high as $1: 200$, different titers being found not only with $M$ protein from different types of streptococci but also with different batches of $M$ protein from the same type of streptococcus. In view of the differences between the preparations, it was evident that a similar titration of $M$ protein would be necessary in all subsequent experiments in order to avoid spontaneous agglutination but still utilize the maximal concentration of antigen for adsorption to erythrocytes.
Because of the possibility that the agglutination observed might be a specific property of $M$ protein, attempts were made to block it by incubating type-specific rabbit sera with the $M$ protein before the addition of the treated erythrocytes. Serial dilutions in amounts of $0.25 \mathrm{cc}$. were made of type 1,14 , and 24 rabbit antistreptococcus sera as well as normal human sera, and to these tubes was added $0.25 \mathrm{cc}$. of a $1: 4$ dilution of type $1 \mathrm{M}$ protein. After incubation at $37^{\circ} \mathrm{C}$. for one hour, $0.5 \mathrm{cc}$. of a 2 per cent suspension of tannic acid-treated erythrocytes was added to each tube. Following two hours in the $37^{\circ} \mathrm{C}$. water bath and overnight refrigeration, readings were made for agglutination of the red cells. It was found that inhibition of agglutination was caused by all of the sera employed in dilutions up to $1: 40$ or $1: 80$. The observations provided no evidence that the agglutination by low dilutions of $M$ protein of tannic acid treated cells is due to the type-specific antigen; the inhibition by unrelated sera suggests that it may represent a nonspecific property of the preparations. Similar hemagglutination was produced by a much more highly purified preparation of type $1 \mathrm{M}$ protein (23), obtained through the courtesy of Dr. Rebecca C. Lancefield.

Type-specific hemagglutination of erythrocytes treated with optimal amounts of tannic acid and $M$ protein. The above experiments showed that the preparation of erythrocytes which were not spontaneously agglutinated by tannic acid or $M$ protein, necessitated the use of tannic acid in a concentration of 0.001 per cent and $M$ protein in a concentration that depended on the agglutinating property of individual preparations. If nonspecific hemagglutination was avoided by these measures, specific agglutination of cells treated with tannic

TABLE I

Agglutination by antistreptococcus rabbit sera of human erythrocytes treated with tannic acid and different concentrations of $M$ protein

\begin{tabular}{|c|c|c|c|c|c|c|c|}
\hline \multirow{2}{*}{$\begin{array}{l}\text { Antistreptococcus } \\
\text { sertm type* }\end{array}$} & \multicolumn{7}{|c|}{ Type $24 \mathrm{M}$ protein dilution $\dagger$} \\
\hline & $1: 64$ & $1: 128$ & $1: 256$ & $1: 512$ & $1: 1024$ & $1: 2048$ & $1: 4096$ \\
\hline 24 & $+\ddagger$ & + & + & + & + & + & - \\
\hline 1 & - & - & - & - & - & - & - \\
\hline Control, no serum & - & - & - & - & - & - & - \\
\hline
\end{tabular}

* A $1: 100$ dilution of the indicated serum was used in all tubes.

$\dagger$ Erythrocytes were treated with 0.001 per cent tannic acid and the indicated dilution of $\mathbf{M}$ protein before being exposed to the serum dilutions.

$\ddagger+$ means agglutination of the erythrocytes; - means no agglutination. 
acid and $M$ protein could be demonstrated by antistreptococcal rabbit serum, as is shown by the following data.

An experiment which illustrates the activity of various amounts of $M$ protein in the hemagglutination test is shown in Table I. Two-fold dilutions of a type $24 \mathrm{M}$ preparation were used for adsorption on the tannic acid-treated cells, as described in the section on Materials and Methods. A $1: 100$ dilution of type 24 rabbit antistreptococcus serum was mixed with cells exposed to each dilution of $M$ protein. Hemagglutination occurred in all tubes through the dilution of $1: 2048$. The specificity of the reaction is indicated by the absence of hemagglutination in control tubes containing type 1 serum or saline. It was evident from the experiment that adsorption of $M$ protein to the treated cells had occurred to an extent sufficient to demonstrate the presence of small quantities of the antigen.

The hemagglutination test with various types of $M$ protein and rabbit antisera. A cross titration of 7 different serological types of rabbit antisera was carried out in the presence of cells which had been prepared with corresponding types of $\mathrm{M}$ protein. In each instance the cells were exposed to a $1: 250$ dilution of $\mathbf{M}$ protein. The results indicate that hemagglutination occurred in high titer with each mixture of serum and homologous $M$ protein (Table II).

Cross-reactions with other types of antisera were observed in the cells treated with type $3 \mathrm{M}$ protein, although the titers obtained with heterologous sera were considerably lower than those with homologous sera. One batch of type 19 rabbit antistreptococcus serum has been observed to cause cross agglutination in high titer with many heterologous types of $\mathrm{M}$ protein.

Figure 1 shows a photograph of a typical test, using type $24 \mathrm{M}$ protein-treated erythrocytes and types $1,5,14$, and 24 rabbit sera. The bottom line of tubes represents a positive reaction with the type 24 serum, beginning with a $1: 100$ dilution and showing an endpoint at $1: 12,800$. The other rows show the typical appearance of negative reactions.

The hemolytic effect of guinea pig complement on treated cells in the presence of specific antiserum. It has been shown that tannic acid-treated human erythrocytes are hemolyzed by human complement, but not by guinea pig complement (18). Accordingly, attempts were made to determine if guinea pig complement, when added to the regular test, would change it to one that could be read by hemolysis instead of hemagglutination. Guinea pig complement was added to the tubes containing the mixtures of $\mathrm{M}$-sensitized cells and antiserum, after the latter had been allowed to stand overnight at $4^{\circ} \mathrm{C}$. After the addition of complement the cells were incubated at $37^{\circ} \mathrm{C}$. for one hour and then read for hemolysis. When preparations of type $24 \mathrm{M}$ protein were used, hemolysis occurred in significant titers. Little or no hemolysis occurred, however, even when the hemagglutinating titers were high, when types $1,3,5$, and $14 \mathrm{M}$ protein and antisera were used. The sensitivity of the hemolytic test using type $24 \mathrm{M}$ protein varied with different batches of the antigen but in all instances showed higher titers than were seen with preparations made from other types of streptococci. The hemolysis seemed to be specific in that none occurred in the absence of specific hemagglutination.

The specific inhibition of hemagglutination by

TABLE II

Titration of antistreptococcus rabbit sera with erythrocytes treated with tannic acid and various types of $M$ protein

\begin{tabular}{|c|c|c|c|c|c|c|c|}
\hline \multirow{2}{*}{$\begin{array}{c}\mathbf{M} \\
\text { protein } \\
\text { type* }\end{array}$} & \multicolumn{7}{|c|}{ Type antistreptococcus rabbit sera } \\
\hline & 1 & 3 & 5 & 12 & 14 & 17 & 24 \\
\hline 1 & $1: 2,560 \dagger$ & $\overline{10} 210$ & $\overline{160}$ & $\overline{150}$ & 一 & - & $\overline{100}$ \\
\hline 3 & $1: 80$ & $1: 10,240$ & $1: 160$ & $1: 160$ & - & - & $1: 640$ \\
\hline 5 & - & - & $1: 5,120$ & - & - & - & - \\
\hline 12 & - & - & - & $1: 2,560$ & - & - & - \\
\hline 14 & - & - & - & - & $1: 1,280$ & - & 一 \\
\hline 17 & - & - & - & - & - & $1: 5,120$ & - \\
\hline 24 & - & - & - & - & - & - & $1: 2,560$ \\
\hline
\end{tabular}
protein.

* Erythrocytes treated with 0.001 per cent tannic acid before being exposed to a 1:250 dilution of the indicated M

$\dagger$ The figures are the highest dilution of serum that agglutinated the red cells. A negative reaction indicates that there was no hemagglutination at a 1:80 dilution or higher. 


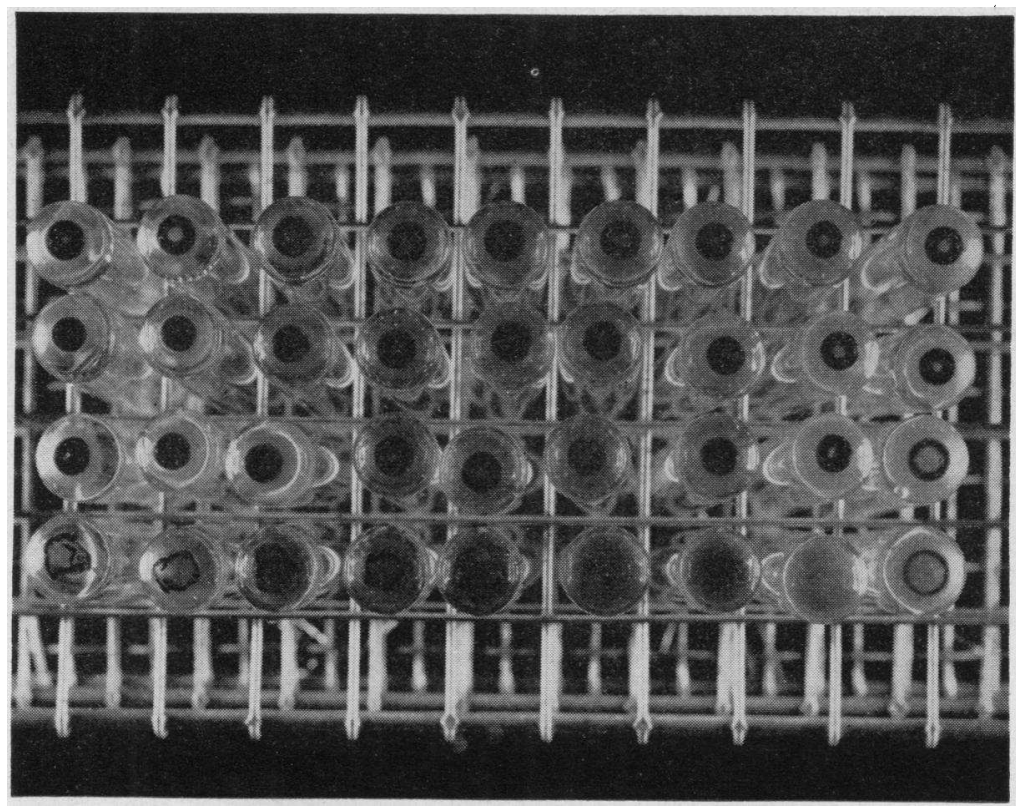

Fig. 1. The Hemagglutination Test Using Rabbit Antistreptococcus Sera and Erythrocytes Treated with Tannic Acid and Type $24 \mathrm{M}$ Protein

The bottom row of tubes shows a positive reaction with type 24 serum. beginning with a 1:100 dilution. The other rows show negative reactions with types 1,5 , and 14 sera.

homologous $M$ protein. In order to study further the degree of specificity of the hemagglutination reaction with erythrocytes treated with tannic acid and $M$ protein, the effect of the addition of homologous and heterologous $M$ protein to the type specific serum before mixing the latter with $M$ protein treated erythrocytes was investigated. The serum was serially diluted in the usual manner, and the erythrocytes were prepared with tannic acid and homologous $\mathrm{M}$ protein. Next, 0.2 cc. amounts of a 1:100 dilution of $\mathrm{M}$ protein were added to the tubes containing the serum dilutions, and the tubes incubated at $37^{\circ} \mathrm{C}$. for one hour. The erythrocytes were then added in the usual manner. When the added $M$ protein was of the same type as the anti-M antibody in the serum, agglutination was inhibited. When the $M$ protein of a heterologous type was used, agglutination was not inhibited; in fact, there sometimes occurred a slight enhancement of agglutination in these tubes. Table III illustrates the results of an experiment showing the blocking effect of adding type $14 \mathrm{M}$ protein to homologous serum before mixing with tannic acid treated erythrocytes.
The hemagglutination test with acute and convalescent sera from patients with streptococcal infections. After it had been demonstrated that rabbit antistreptococcus sera would specifically agglutinate erythrocytes treated with tannic acid and $\mathrm{M}$ protein, attempts were made to determine if specific antibodies could be demonstrated in the sera of patients convalescent from Group A streptococcal infections. Acute and convalescent sera were obtained from patients with streptococcal upper respiratory infections; typeable group A streptococci had been isolated in large numbers in cultures of the throats of these patients, and typespecific bactericidal antibodies had been demonstrated in the convalescent sera of all. The sera were tested with erythrocytes sensitized with homologous $\mathrm{M}$ protein, and also with control cells prepared with heterologous $M$ protein. The results of one such experiment using sera from patients with type 24 streptococcal infections and erythrocytes treated with types 24 and $14 \mathrm{M}$ protein are shown in Table IV. In five of the six patients there was a two-fold or greater increase in the agglutination titer of the convalescent serum 
TABLE III

The effect of homologous and heterologous $M$ protein on the agglutination by type 14 rabbit serum of type 14 $M$ protein-treated erythrocytes

\begin{tabular}{ccccccc}
\hline \hline \multirow{2}{*}{$\begin{array}{c}\text { Type } \\
\text { of } M \\
\text { protein } \\
\text { added* }\end{array}$} & \multicolumn{5}{c}{ Dilution of type 14 rabbit serum } \\
\cline { 2 - 7 } & $1: 100$ & $1: 200$ & $1: 400$ & $1: 800$ & $1: 1,600$ & $1: 3,200$ \\
\hline 14 & - & - & - & - & - & - \\
1 & + & + & + & + & + & - \\
5 & + & + & + & + & + & - \\
24 & + & + & + & + & + & - \\
none, & + & + & + & + & - & - \\
control & + & + & + & & &
\end{tabular}

* A 1:100 dilution of the indicated $M$ protein was added to each serum dilution, and these incubated for one hour before adding the treated erythrocytes.

† Erythrocytes were treated with 0.001 per cent tannic acid and a $1: 250$ dilution of type $14 \mathrm{M}$ protein before being exposed to the indicated serum dilutions.

for the homologous antigen. No hemagglutination occurred with either the acute-phase or convalescent serum of one patient.

Table IV also shows that reactions of the same pairs of sera occurred with erythrocytes treated with type $14 \mathrm{M}$ protein. Hemagglutination was noted in four of the six pairs of sera; there was an increase in titer with one pair of sera while the other three showed the same titers in the acutephase and convalescent sera.

Acute and convalescent phase sera from patients with infections due to types $1,5,14$, and 24 streptococci have also been tested for the presence of hemagglutinating antibodies. Significant increases have been demonstrated in the convalescent sera in the majority of cases with the homologous type of $\mathrm{M}$ protein. In addition, however, nonspecific cross reactions similar to those described above were encountered in a high percentage of cases.

In most instances there was direct correlation between the presence of type-specific bactericidal antibodies and type-specific hemagglutinating antibodies. In several cases, however, hemagglutination did not occur with sera known to contain bactericidal antibody, suggesting the possibility that the antibodies responsible for the two reactions may not be identical.

The blocking effect of heterologous $M$ preparations on nonspecific cross-reactions. The occurrence of nonspecific cross-reactions in the hemagglutination test with human sera might be explained by the presence of antibodies other than anti-M, presumably reacting with contaminating antigenic materials contained in the crude $\mathrm{M}$ preparations. Attempts to circumvent this difficulty by employing a more highly purified $\mathrm{M}$ preparation, supplied by Dr. Lancefield, were unsuccessful. Therefore, the possible blocking effect of heterologous $M$ preparations on the cross-reactions was investigated. An illustrative experiment in which this was accomplished, and cross-reactions eliminated, is shown in Table V. The serum was from a patient convalescent from a type 24 streptococcal infection and contained bactericidal antibodies to type 24 streptococcus but not to type 14 streptococcus; there were, however, hemagglutinating antibodies reacting with both types. When $0.2 \mathrm{cc}$. of a $1: 100$ dilution of type $3 \mathrm{M}$ protein was added to each tube, and the tubes incubated at $37^{\circ} \mathrm{C}$. for one hour before the addition of the $\mathrm{M}$ proteintreated erythrocytes, the titer of type 24 antibodies was not altered but the reaction with cells treated with type $14 \mathrm{M}$ was markedly inhibited.

Some preparations of $\mathrm{M}$ protein were more effective than others in the inhibition of nonspecific

TABLE IV

Agglutination of erythrocytes treated with tannic acid and types 24 and $14 M$ protein by sera from patients with type 24 streptococcal infections

\begin{tabular}{|c|c|c|c|}
\hline \multirow[b]{2}{*}{ Patient } & \multirow[b]{2}{*}{ Serum* } & \multicolumn{2}{|c|}{ Agglutination titer } \\
\hline & & $\begin{array}{l}\text { Type } 24 \dagger \\
\text { M protein }\end{array}$ & $\begin{array}{c}\text { Type } 14 \\
\text { Mrotein }\end{array}$ \\
\hline 1 & $\begin{array}{l}\text { Acute } \\
\text { conv. }\end{array}$ & $\underset{1: 640}{\ddagger}$ & $\begin{array}{l}1: 1,280 \\
1: 640\end{array}$ \\
\hline 2 & $\begin{array}{l}\text { Acute } \\
\text { conv. }\end{array}$ & $\overline{1: 640}$ & $\begin{array}{l}1: 640 \\
1: 1,280\end{array}$ \\
\hline 3 & $\begin{array}{l}\text { Acute } \\
\text { conv. }\end{array}$ & $\begin{array}{l}1: 160 \\
1: 640\end{array}$ & $\begin{array}{l}1: 160 \\
1: 2,560\end{array}$ \\
\hline 4 & $\begin{array}{l}\text { Acute } \\
\text { conv. }\end{array}$ & - & - \\
\hline 5 & $\begin{array}{l}\text { Acute } \\
\text { conv. }\end{array}$ & $1 \overline{280}$ & - \\
\hline 6 & $\begin{array}{l}\text { Acute } \\
\text { conv. }\end{array}$ & $\begin{array}{l}1: 40 \\
1: 160\end{array}$ & $\begin{array}{l}1: 80 \\
1: 160\end{array}$ \\
\hline
\end{tabular}

* Acute phase serum was obtained at the time of the streptococcal illness, convalescent serum approximately three weeks later. I

+ Erythrocytes were treated with 0.001 per cent tannic acid and a 1:250 dilution of $M$ protein before being exposed to the serum dilutions.

$\ddagger$ The figures are the highest dilution of serum that agglutinated the red cells. A negative reaction indicates that there was no hemagglutination at a 1:10 dilution or higher. 
TABLE V

Effect on nanspecific hemagglutination of the addition of heterologous $M$ protein and normal rabbit serum

\begin{tabular}{|c|c|c|c|c|c|c|c|c|c|c|c|c|c|c|}
\hline \multirow{3}{*}{ Material added* } & \multicolumn{14}{|c|}{ Serum dilutions } \\
\hline & \multicolumn{7}{|c|}{ Type 24 antiserum and type 24 cells } & \multicolumn{7}{|c|}{ Type 24 antiserum and type 14 cells } \\
\hline & $1: 20$ & $1: 40$ & $1: 80$ & $1: 160$ & $1: 320$ & $1: 640$ & $1: 1,280$ & $1: 20$ & $1: 40$ & $1: 80$ & $1: 160$ & $1: 320$ & $1: 640$ & $1: 1,280$ \\
\hline $\begin{array}{l}\text { Type } 3 \\
\text { M protein } \dagger\end{array}$ & $3 \S$ & 2 & 2 & 1 & 1 & 1 & 一 & \pm & \pm & - & - & - & - & 一 \\
\hline Saline & 3 & 3 & 3 & 3 & 1 & 1 & - & 3 & 3 & 2 & 2 & 2 & 2 & 1 \\
\hline $\begin{array}{l}\text { N.R.S. } \ddagger \text { and type } 3 \\
\text { M protein }\end{array}$ & 3 & 3 & 3 & 3 & 3 & 3 & - & 一 & - & - & - & - & - & - \\
\hline N.R.S. $\ddagger$ & 3 & 3 & 3 & 3 & 3 & 2 & - & 3 & 3 & 3 & 3 & 3 & 3 & - \\
\hline
\end{tabular}

* Material indicated added to each dilution of antiserum one hour before the addition of the treated erythrocytes. † $0.2 \mathrm{cc}$. of a $1: 100$ dilution added to each serum dilution.

Indicates normal rabbit serum; a 1 per cent solution in 0.75 per cent saline was used as the diluting fluid.

$\$$ The numbers indicate the degree of agglutination of the red cells. 1 means slight but definite agglutination, and 2 and 3 mean more marked agglutination.

hemagglutination; one batch of type $3 \mathrm{M}$ protein has been the most effective in experiments performed to this time. It should be noted that this batch of $\mathrm{M}$ protein apparently contains a large amount of non- $\mathrm{M}$ antigen since it has been associated with many nonspecific reactions when adsorbed to erythrocytes and tested with heterologous sera.

Boyden (19) reported that the stability of tannic-acid treated cells was improved by the use of normal rabbit serum in the diluting fluid. The effect of using 1 per cent rabbit serum in 0.75 per cent saline as the diluent for antiserum was therefore investigated in experiments dealing with the blocking effect of heterologous $M$ protein. It was found that the degree of agglutination was much enhanced in mixtures of antisera with homologous $\mathrm{M}$ antigen, and the elimination of cross-reactions by blocking with heterologous $M$ preparations was made more clear cut. The improvement of the test by normal rabbit serum is illustrated in Table V.

These methods for improving the specificity of the test are now being applied in tests of sera from patients with streptococcal infections and rheumatic fever, to be reported in a subsequent communication.

\section{DISCUSSION}

Attempts to bring about the adsorption of $M$ protein to the surface of human erythrocytes, for the purpose of demonstrating anti- $M$ protein antibody by hemagglutination, were unsuccessful when untreated red cells were employed. Kirby (16), in a study of the hemagglutination reaction with a mixture of streptococcal antigenic materials, was also unable to produce type-specific reactions indicating the presence of $\mathrm{M}$ protein on the erythrocytes.

The treatment of human group $\mathrm{O}$ erythrocytes with small amounts of tannic acid has made possible the adsorption to the cell surface of the $M$ protein of group A streptococci. Erythrocytes so treated are selectively agglutinated by antistreptococcus rabbit sera and by the sera of humans convalescent from streptococcal infections. In the tests with human sera, however, non-specific crossreactions with other types of $M$ have occurred in a sufficiently high percentage of cases to make the use of the test, without modification, impractical.

The non-specific hemagglutination appeared to be due to an antibody reacting with unidentified antigenic material contained in the $M$ protein preparations. The titer of this antibody did not appear to be related to the titer of specific $M$ antibody. In some cases increased levels of both kinds of antibody were demonstrated in convalescent sera; in others, however, there was a rise in specific $M$ antibody while both the acute-phase and convalescent sera showed equally high titers of heterologous hemagglutinating antibody.

The non-specific cross-reactions could be in- 
hibited by the addition of a heterologous $\mathrm{M}$ preparation to the serum before mixing the latter with M-treated erythrocytes. Some batches of $M$ were more effective than others; the more effective batches were those that seemed to contain relatively large amounts of non-specific antigenic material. The amount of heterologous antigen required to block cross-reactions was sometimes difficult to determine without detailed titrations, because of the occurrence of spontaneous agglutination in the presence of excess $M$ protein. The addition of normal rabbit serum to the diluent considerably improved the test; specific agglutination was enhanced, and the inhibition of non-specific agglutination by heterologous $\mathrm{M}$-preparations was more clear-cut. Studies are now in progress to determine if the test can be made practical for routine use by these modifications.

A possible solution to some of the problems in the hemagglutination test was the conversion of the test, by the addition of guinea pig complement, to one read by hemolysis. Attempts to do this were disappointing, since significant degrees of hemolysis occurred only in tests in which type 24 protein and antibody were employed. The reason for the failure to show hemolysis with tests involving other types of antigen and antibody is not known.

Much care was necessary in the treatment of erythrocytes with tannic acid and M protein. The spontaneous agglutination due to tannic acid could be prevented by determining the agglutinating property of each lot of tannic acid before use. It was more difficult to select the concentration of $M$ protein that did not cause agglutination of the erythrocytes but was adsorbed in sufficient quantities to react with antibody. In using specific rabbit anti-sera this was not a great problem; the $M$ antibodies were of such high levels that erythrocytes treated with very small amounts of antigen were agglutinated. With human sera, however, it was desirable to use as great a concentration of antigen as possible without causing spontaneous agglutination, in order to detect small amounts of antibody. Each batch of $\mathrm{M}$ protein required, therefore, detailed titrations to determine the optimal amounts for the.preparation of sensitized cells.

\section{SUMMARY}

1. M Protein of group A streptococci was adsorbed to human group $\mathrm{O}$ erythrocytes previously exposed to small amounts of tannic acid, and these cells were specifically agglutinated by homologous rabbit antistreptococcus sera and sera of some patients convalescent from streptococcal infection.

2. The addition of guinea pig complement to the hemagglutination test resulted in significant specific hemolysis when type $24 \mathrm{M}$ protein and antiserum were used; little or no hemolysis occurred when other types of $\mathrm{M}$ protein and antisera were involved.

3. Hemagglutination was specifically inhibited by the addition of homologous $M$ protein to the serum before the addition of the $M$ protein-sensitized erythrocytes.

4. In a study of human sera the appearance of type-specific hemagglutinins was demonstrated during convalescence from streptococcal infection. However, non-specific hemagglutination was frequently encountered. This could be inhibited in some instances by incubating the serum with a heterologous $\mathrm{M}$ preparation before the addition of the treated erythrocytes. Specific agglutination, and the inhibition of non-specific agglutination by heterologous $M$ protein, were made more clearcut by the use of normal rabbit serum in the diluting fluid.

\section{ACKNOWLEDGMENTS}

The authors wish to thank Mr. Dale Hendrickson, Miss Agnes Opstad, and Miss Betty Smithwick for assistance in these studies.

\section{REFERENCES}

1. Watson, R. F., Rothbard, S., and Swift, H. F., Typespecific protection and immunity following intranasal inoculation of monkeys with group $\mathrm{A}$ hemolytic streptococci. J. Exper. Med., 1946, 84, 127.

2. Wannamaker, L. W., and Denny, F. W., Demonstration in man of type specific immunity to streptococcal infections. J. Clin. Invest., 1952, 31, 669.

3. Rantz, L. A., Kirby, W. M. M., and Jacobs, A. H., Group A hemolytic streptococcus antibodies. I. Griffith type agglutinin and antistreptolysin titers in normal men and in acute infections. J. Clin. Invest., 1943, 22, 411.

4. Swift, H. F., and Hodge, B. E., Type-specific anti-M precipitins in rheumatic and non-rheumatic patients with hemolytic streptococcal infections. Proc. Soc. Exper. Biol. \& Med., 1936, 34, 849.

5. Diefendorf, H. W., A method for detecting in human serum protective bodies against hemolytic streptococci. Proc. Soc. Exper. Biol. \& Med., 1941, 48, 56. 
6. Kuttner, A. G., and Lenert, T. F., The occurrence of bacteriostatic properties in the blood of patients after recovery from streptococcal pharyngitis. J. Clin. Invest., 1944, 23, 151.

7. Rothbard, S., Bacteriostatic effect of human sera on group A streptococci. I. Type-specific antibodies in sera of patients convalescing from group A streptococcal pharyngitis. J. Exper. Med., 1945, 82, 93.

8. Middlebrook, G., and Dubos, R. J., Specific serum agglutination of erythrocytes sensitized with extracts of tubercle bacilli. J. Exper. Med., 1948, 88, 521.

9. Rothbard, S., Dooneief, A. S., and Hite, K. E., Practical application of a hemagglutination reaction in tuberculosis. Proc. Soc. Exper. Biol. \& Med., 1950, 74, 72.

10. Warburton, M. F., Keogh, E. V., and Williams, S. W., A hæmagglutination test for the diagnosis of influenzal meningitis. M. J. Australia, 1949, 1, 135.

11. Norden, A., Agglutination of sheep's erythrocytes sensitized with histoplasmin. Proc. Soc. Exper. Biol. \& Med., 1949, 70, 218.

12. Boyden, S. V., Adsorption by erythrocytes of antigens of 'Pfeifferella mallei' and 'Pfeifferella whitmori.' Proc. Soc. Exper. Biol. \& Med., 1950, 73, 289.

13. O'Connor, J. L., and MacDonald, J. M., Excretion of specific antigen in the urine in Tsutsugamushi Disease (scrub typhus). Brit. J. Exper. Path., 1950, 31, 51.

14. Burnet, F. M., Modification of human red cells by virus action. III. A sensitive test for mumps antibody in human serum by the agglutination of human red cells coated with a virus antigen. Brit. J. Exper. Path., 1946, 27, 244.

15. Wright, G. G., and Feinberg, R. J., Hemagglutination by tularemia antisera: Further observations on agglutination of polysaccharide-treated erythrocytes and its inhibition by polysaccharide. J. Immunol., 1952, 68, 65 .

16. Kirby, W. M. M., Hemagglutination reaction in streptococcal infections and acute rheumatic fever. Proc. Soc. Exper. Biol. \& Med., 1951, 78, 519.

17. Neter, E., Bertram, L. F., Zak, D. A., Murdock, M. R., and Arbesman, C. E., Studies on hemagglutination and hemolysis by Escherichia coli antisera. J. Exper. Med., 1952, 96, 1.

18. Peck, J. L., and Thomas, L., Studies on the hemolysis of human erythrocytes by homologous complement in the presence of tannic acid. Bull. Johns Hopkins Hosp., 1949, 84, 216.

19. Boyden, S. V., The adsorption of proteins on erythrocytes treated with tannic acid and subsequent hemagglutination by antiprotein sera. J. Exper. Med., 1951, 93, 107.

20. Alsever, J. B., and Ainslie, R. B., A new method for the preparation of dilute blood plasma and the operation of a complete transfusion service. New York State J. Med., 1941, 41, 126.

21. Swift, H. F., Wilson, A. T., and Lancefield, R. C., Typing group A hemolytic streptococci by $M$ precipitin reactions in capillary pipettes. J. Exper. Med., 1943, 78, 127.

22. Lancefield, R. C., The antigenic complex of streptococcus hæmolyticus. I. Demonstration of a typespecific substance in extracts of streptococcus hæmolyticus. J. Exper. Med., 1928, 47, 91.

23. Lancefield, R. C., and Perlmann, G. E., Preparation and properties of type-specific $M$ antigen isolated from a group A, type 1 hemolytic streptococcus. J. Exper. Med., 1952, 96, 71. 